\title{
ASPECTS OF SATISFACTION OF EMALINE CUSTOMERS
}

\author{
Liliana Dewi \& Raynaldo Aditya Siandika \\ Universitas Ciputra Surabaya
}

\begin{abstract}
In order to achieve the objectives of the operations, Emaline needs to review the influence of product quality; which consists of aesthetics, durability, customer perceived quality, and serviceability, on the customer satisfaction of the company. The purpose of this study is to determine: the influence of aesthetics on customer satisfaction; the influence of durability on customer satisfaction; the influence of customer perceived quality on customer satisfaction; and the influence of serviceability on customer satisfaction. The samples in this research consist of 42 Emaline consumers under the business-to-consumer pattern who have made more than one purchase. Multiple Linear Regression is used as analysis technique in this study. Research results suggest that aesthetics, durability, customer perceived quality, and serviceability affect the customer satisfaction of Emaline.
\end{abstract}

Keywords: aesthetics, customer perceived quality, customer satisfaction, durability, serviceability

\section{INTRODUCTION}

Judging from the value of gross domestic product, the leather industry (including, textile, leather, and footwear) shows that there is a trend to improve businesses. The improvement gives an understanding to employers that the leather industry is experiencing growth and has many potentials. The potentials in that industry should be utilized to enable Emaline to increase its number of customers and expand its businesses. Customers satisfaction needs more attention and it is not something that appears suddenly. Yesenia and Siregar (2014:183), and Sembiring et al. (2014:1), suggest that product quality has a significant effect to customers satisfaction.

Wendha et al. (2013:20) explains that the existence of consumer satisfaction in the company can reduce consumer sensitivity to prices, the cost of marketing failure, operating costs

\footnotetext{
*Corresponding Author.

e-mail: Ldewi@ciputra.ac.id
}

due to the increasing number of consumers, increase advertising effectiveness and business reputation. This view explains the importance of customer satisfaction for companies, so Emaline needs to be investigated. As explained earlier, product quality can affect customer satisfaction. Alfred (2013: 184-185) explains that product quality has a number of variables that can determine the extent of the quality of the product itself, which the variables include: performance, feature, conformance, reliability, durability, serviceability, aesthetics, and customer perceived quality.

The researcher conducted a preliminary survey of the variables of product quality in order to see the variables of product quality that had more influence on customer satisfaction. In Table 1 which contains the results of the initial survey it can be seen that consumers pay more attention to aesthetics, durability, customer perceived quality, and serviceability aspects. The results of the initial survey became the initial reference for reviewing product quality, specifically aesthetics, durability, customer 
Liliana Dewi, Raynaldo Aditya Siandika / Aspects of Satisfaction of Emaline Customers /

JEE, Vol. 7, No. 1, March 2018, pp 43-48

Table 1 Preliminary Survey Result

\begin{tabular}{|c|cccc|}
\hline Respondents & $\begin{array}{c}\text { Times of } \\
\text { Purchasing } \\
\text { Emaline }\end{array}$ & $\begin{array}{c}\text { Costumer } \\
\text { Residence } \\
\text { Area }\end{array}$ & $\begin{array}{c}\text { Aspects of Emaline Products } \\
\text { that Satisfies Consumers }\end{array}$ & \\
\hline 1. & 2 times & Surabaya & $\begin{array}{c}\text { The models are good looking } \\
\text { (aesthetics) }\end{array}$ & $\begin{array}{c}\text { The models are good } \\
\text { looking (aesthetics) }-6 \\
\text { persons or 60\% }\end{array}$ \\
\cline { 1 - 4 } 2. & 1 time & Surabaya & $\begin{array}{c}\text { The bags look durable } \\
\text { (durability) }\end{array}$ & $\begin{array}{c}\text { The bags look durable } \\
\text { (durability) }-2\end{array}$ \\
persons or 20\%
\end{tabular}

Source: Preliminary Survey Result (February, 2016)

perceived quality, and serviceability and its effects on customer satisfaction Emaline.

Based on previous explanations, researchers conducted research on aspects of aesthetics, durability, customer perceived quality, and serviceability of product quality and its effect on Emaline customer satisfaction. That research was entitled "The Effect of Aesthetics, Durability, Customer Perceived Quality, and Serviceability on Emaline Consumer Satisfaction".

Ehsani and Ehsani (2014) conducted a study to review the effect of product quality and prices on customer satisfaction and consumer commitment to motor vehicles. The research was conducted using a quantitative approach to obtain the desired research results. The collected data were processed and analyzed by the SEM (Structural Equation Modeling) technique.
The results showed that product quality can affect consumer satisfaction. Rizwan et al. (2014) conducted a study to review matters that could affect the satisfaction and loyalty of consumers of Nokia products. The research was conducted using a quantitative approach to obtain the desired research results and comprehensively involves 170 respondents. The collected data were processed and analyzed by factor analysis techniques. The results showed that product quality can affect consumer satisfaction. Yesenia and Siregar (2014) conducted a study to review the effect of service quality and product quality on consumer satisfaction and loyalty at Kentucky Fried Chicken. The research was conducted using a quantitative approach to obtain the desired research results and thoroughly involved 100 respondents. The collected data 
were processed and analyzed by the SEM (Structural Equation Modeling) technique. The results showed that product quality can have a significant effect on customer satisfaction. Yesenia and Siregar (2014: 16) suggest that product quality can have a significant effect on customer satisfaction. According to Andrias et al. (2015:21), aesthetics, durability, customer perceived quality, and serviceability have a significant effect on customer satisfaction. The conceptual model of this research as shown in Figure 1 and the research hypothesis is as follows:

$\mathrm{H}_{1}$ Aesthetics has an effect on Emaline customer satisfaction.

$\mathrm{H}_{2}$ Durability has an effect on Emaline customer satisfaction.

$\mathrm{H}_{3}$ Customer perceived quality has an effect on Emaline customer satisfaction.

$\mathrm{H}_{4}$ Serviceability has an effect on Emaline customer satisfaction.

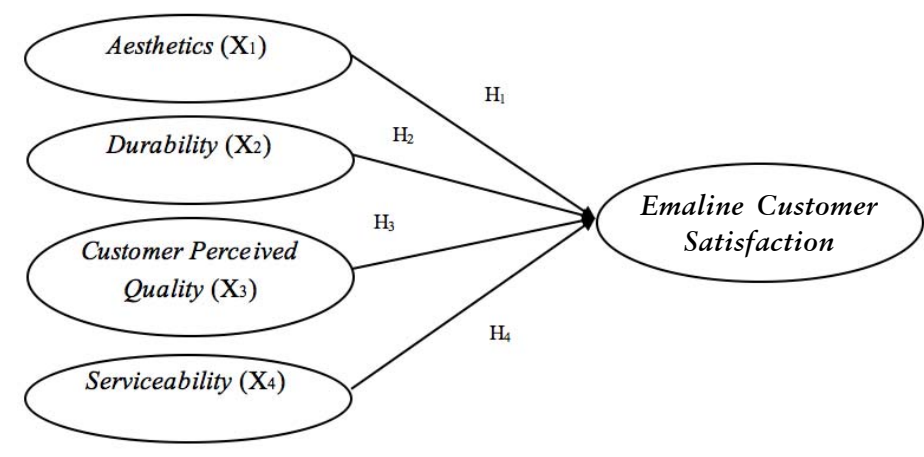

Figure 1 Conceptual Model

\section{METHOD}

The researched variables are aesthetics, customer perceived quality, durability, consumer satisfaction and Serviceability. The samples taken in this study were 42 respondents who had purchased Emaline products more than once. The sampling was done randomly. The data were analyzed using multiple linear regressions.

\section{RESULT}

The subjects of this study can be characterized according to the times of product purchases as shown in Table 2

Table 2 The Distribution of Product Purchases from the Respondents

\begin{tabular}{|c|ccc|}
\hline No. & Times of Purchases & Amount & Percentage \\
\hline 1 & 2 times & 22 persons & $52.4 \%$ \\
\hline 2 & 3 times & 19 persons & $45.2 \%$ \\
\hline 3 & More than 3 times & 1 person & $2.4 \%$ \\
\hline & TOTAL: & 42 persons & $100 \%$ \\
\hline
\end{tabular}

Based on the data in Table 2, it turns out that the distribution is more dominated by customers who have made purchases 2 times (22 Emaline customers, or $52.4 \%$ of respondents).

Table 3 The Distribution of the Amount of Money Allocated by the Customers to Buy Products Similar to Emaline

\begin{tabular}{|c|c|c|c|}
\hline No. & $\begin{array}{l}\text { The Distribution of the } \\
\text { Amount of Money } \\
\text { Allocated by the Customers } \\
\text { to Buy Products Similar to } \\
\text { Emaline }\end{array}$ & Amount & Percentage \\
\hline 1 & $<\mathrm{Rp} 1.000 .000$ & - & - \\
\hline 2 & Rp1.000.000 - Rp2.000.000 & 22 persons & $52.4 \%$ \\
\hline 3 & More than Rp2.000.000 & 20 persons & $47.6 \%$ \\
\hline \multicolumn{2}{|r|}{ TOTAL: } & 42 persons & $100 \%$ \\
\hline
\end{tabular}

Based on the data in Table 3, it turns out that the distribution is more dominated by customers who allocate Rp. 1.000 .000 to $\mathrm{Rp}$ 2.000.000 to buy products similar to Emaline (22 Emaline customers, or $52.4 \%$ of respondents).

The Value of Cronbach's Alpha of lifestyle variable $\left(\mathrm{X}_{1}\right)$, perception variable $\left(\mathrm{X}_{2}\right)$, and purchase decision variable $(\mathrm{Y})$ are all greater than 0.6 , which means all research variables can be said to be reliable. The sig. value of $F$ test is $\leq$ 0.05 (that is equal to 0.000 ), thus it can be concluded that aesthetics, durability, customer perceived quality, and serviceability variables 
Liliana Dewi, Raynaldo Aditya Siandika / Aspects of Satisfaction of Emaline Customers /

JEE, Vol. 7, No. 1, March 2018, pp 43-48

simultaneously or jointly have a significant effect on the satisfaction of Emaline customer satisfaction.

The results of the $t$ statistic test have shown that the significance value for the aesthetics variable is 0.018 , which the value is smaller than 0.05 , so it can be concluded that the aesthetics variable partially has a significant effect on the customer satisfaction variable. The significance value for variable durability is 0.005 , which the value is smaller than 0.05 , so it can be concluded that the durability variable partially has a significant effect on the variable customer satisfaction. The significance value for the customer perceived quality variable is 0.021 , which the value is smaller than 0.05 , so it can be concluded that the customer perceived quality variable partially has a significant effect on the customer satisfaction variable. The significance value for the serviceability variable is 0.001 , which the value is smaller than 0.05 , so it can be concluded that serviceability variables partially had a significant effect on customer satisfaction variables. The correlation coefficient obtained is equal to 0.958 , so it can be said that the relationship between independent variables, namely aesthetics (X1), durability (X2), customer perceived quality (X3), and serviceability (X4) variables with dependent variables, namely consumer satisfaction variable is very strong or tight because the value of the correlation coefficient is close to number one. On the other hand, the coefficient of determination obtained is equal to 0.918 , so it can be concluded that $91.8 \%$ of the variation in the variable customer satisfaction can be explained by aesthetics, durability, customer perceived quality and serviceability and the remaining $8.2 \%$ is influenced by other variables not included in the research.
The classic assumption test was carried out in the study. Based on VIF value data from aesthetics, durability, customer perceived quality, and serviceability variables, the value is $<10$. This shows there is no multicollinearity problem in this study and it confirms the feasibility of multiple linear regression analysis techniques that were carried out. The Glejser test results show that the $t$ sig. value is $>0.05$, so it can be concluded that there are no symptoms of heteroscedasticity in the study and this confirms the feasibility of multiple linear regression analysis techniques in this study. The Durbin Watson value is 1.936 , indicating that the Durbin Watson value is already between the dU - (4-dU) range, so we can understand that autocorrelation did not occur in this study and it reinforces the serviceability of multiple linear regression analysis techniques in this study (according to the table Durbin Watson in Appendix F, the value of $\mathrm{dU}$ in this study is 1.72 , so the value of Durbin Watson in the study is in the range of 1.72-2.28). Based on the sig.value data, in the Kolmogorov-Smirnov test, it was 0.613 ( $>0.05$ ), so the conclusion of the residuals was normally distributed and this reinforced the feasibility of multiple linear regression analysis techniques in this study. Linearity tests can be carried out through a test of linearity. The criteria that apply, if the value of sig. in linearity is 0.05 , it can be concluded that between independent variables and dependent variables there is a linear relationship. The data show that the sig. value on linearity of $\mathrm{X}_{1}$ to $\mathrm{Y}, \mathrm{X}_{2}$ to $\mathrm{Y}, \mathrm{X}_{3}$ to $\mathrm{Y}$, and $\mathrm{X}_{4}$ to $\mathrm{Y}$ is $0,000(0.05)$ each, and it shows that between independent variables and dependent variables, there is a linear relationship.

\section{DISCUSSION}

The first hypothesis of "aesthetics influences the satisfaction of Emaline customer" can 
be accepted. The explanation of the efforts or the implication for Emaline is related to the aesthetics variable is as follows.

The result of the research shows that aesthetics has a significant effect on the satisfaction of Emaline customer. Before the research (in this current time), there has been no scientific review conducted by Emaline to prove the influence of aesthetics on the satisfaction of Emaline customer. After the research, the implication for Emaline is that it needs to pay attention to the latest references to the color of the bags that are popular with consumers and models that are valued both by consumers. It is also implied that Emaline needs to improve models that are less favored (to know the model of a good bag or not, Emaline can conduct regular surveys to consumer).

The second hypothesis of "durability influences the satisfaction of Emaline customer" can be accepted. The explanation of the efforts or the implication for Emaline is related to the durability variable is as follows.

The result of the research shows that durability has a significant effect on the satisfaction of Emaline customer. Before the research (in this current time), there has been no scientific review conducted by Emaline to prove the influence of durability on the satisfaction of Emaline customer. After the research, the implication for Emaline is that it needs to consider producing products with better quality that are still affordable to the customer. It has to conduct a periodical survey (e.g., once every three months) to see the durability of its products, thus enabling Emaline to fix issues among its products and eventually improve them.

The third hypothesis of "customer perceived quality influences the satisfaction of Emaline customer" can be accepted. The explanation of the efforts or the implication for Emaline is related to the customer perceived quality variable is as follows.

The result of the research shows that customer perceived quality has a significant effect on the satisfaction of Emaline customer. Before the research (in this current time), there has been no scientific review conducted by Emaline to prove the influence of customer perceived quality on the satisfaction of Emaline customer. After the research, the implication for Emaline is that it needs to pay attention to: 1 ) Customer education to make them understand the characteristics of Emaline products. 2) Customer education on how to maintain Emaline product to retain their quality. 3) Periodical survey (e.g., once every three months) to see the durability of its products, thus enabling Emaline to fix issues among its products and eventually improve them.

The third hypothesis of "serviceability influences the satisfaction of Emaline customer" can be accepted. The explanation of the efforts or the implication for Emaline is related to the serviceability variable is as follows.

The result of the research shows that serviceability has a significant effect on the satisfaction of Emaline customer. Before the research (in this current time), there has been no scientific review conducted by Emaline to prove the influence of serviceability on the satisfaction of Emaline customer. After the research, the implication for Emaline is that it needs to pay attention to: 1) A clear communication line to receive complaints or questions from the customers. 2) A warranty program for the products to ensure that the customer feel satisfied and not to hesitate to buy Emaline products.

This research can conclude that aesthetics, durability, customer perceived quality and serviceability variables have a significant effect on the customer satisfaction variable. The research carried out only covers the field of fashion business and exclusive to Emaline customers, thus the result of this research is difficult to use in other business fields. This research uses a questionnaire to obtain data from the respondents considering the limited time that this research has, thus the answers collected from the questionnaire can be less profound. 
For other research in the future, it is recommended to expand the scope of the research and examine other independent variables (for example: service quality) that can affect customer satisfaction.

\section{REFERENCES}

Alfred, O. 2013. Influences of Price and Quality on Consumer Purchase of Mobile Phone in The Kumasi Metropolis in Ghana a Comparative Study. European Journal of Business and Management, 5(1), 179-199.

Andrias, C.H., Imamah, N., Agus. 2015. Pengaruh Kualitas Produk Terhadap Kepuasan Pelanggan Shampoo Merek Sunsilk di Kota Surabaya. E-Jurnal Manajemen Branchmarck, 1(1), 14-24.

Ehsani, Z., Ehsani M.H. 2014. Effect of Quality and Price on Customer Satisfaction and Commitment in Iran Auto Industry. International Journal of Science, Management, and Engineering, 1(5), 52-56.

Rizwan, M., Umair, M.A., Fiaz, A., Rashid, Q. 2014. Determinants of Customer Satisfaction and Its Impact on Customer Loyalty in Nokia Brand. Journal of Sociological Research, 5(1), 430-488.

Wendha, A.A.A.A.P., Rahyuda, I.K., \& Suasana, I.G.A.K.G. 2013. Pengaruh Kualitas Layanan Terhadap Kepuasan dan Loyalitas Pelanggan Garuda Indonesia di Denpasar. Jurnal Manajemen, Strategi Bisnis, dan Kewirausahaan, 7(1), 19-28.

Yesenia \& Siregar, E.H. 2014. Pengaruh Kualitas Layanan dan Produk Terhadap Kepuasan Serta Loyalitas Pelanggan Kentucky Fried Chicken di Tangerang Selatan. Jurnal Manajemen dan Organisasi, 5(3), 183-199. 